\title{
Increased Susceptibility to Pseudomonas syringae pv. syringae and Pseudomonas viridiflava of Kiwi Plants having Transgenic rolABC genes and its Inheritance in the T1 Offspring
}

\author{
G. M. Balestra', E. Rugini ${ }^{2}$ and L. Varvaro' \\ Authors' address: 'Dipartimento di Protezione delle Piante and ${ }^{2}$ Dipartimento di Produzione vegetale, Università della Tuscia, \\ Via S. Camillo de Lellis, I-01100, Viterbo, Italy (correspondence to E. Rugini, E-mail: rugini@unitus.it) \\ With 2 figures
}

Received October 21, 1999; accepted March 16, 2000

Keywords: Pseudomonas syringae pv. syringae, Pseudomonas viridiflava, bacterial resistance, kjwi plant, rolABC genes, Actinidia deliciosa, transgenic plants

\begin{abstract}
The staminate kiwi (Actinidia deliciosa A. Chev) cv. GTH (Late Yellow Hayward) showed high resistance to the pathogens Pseudomonas syringae pv. syringae and Pseudomonas viridiflava, contrary to the pistillate cv. Hayward which was highly susceptible to both bacteria. The resistant staminate GTH acquired susceptibility when transformed with rolABC of Agrobacterium rhizogenes. This susceptibility was inherited by the $\mathrm{Tl}$ offspring containing $\operatorname{rol} A B C$ genes, derived by crossing pollen of transgenic rolABC GTH with the pistillate cv. Hayward. The susceptibility was probably correlated to high nitrogen content in the leaves of the rolABC plants. The higher susceptibility to $P$. s. pv. syringae than to $P$. viridiflava could be correlated with the high degree of auxin production by first bacterium. The high resistance to both bacteria of the staminate GTH was inherited by all the offspring lacking rol $A B C$ genes. The possibility of reducing susceptibility of rol $A B C$ plants to the pathogens by applying fewer fertilizers in the orchards, which would reduce both costs and environmental impact, is discussed.
\end{abstract}

\section{Zusammenfassung}

Erhöhte Anfälligkeit gegenüber Pseudomonas syringae pv. syringae und Pseudomonas viridiflava in transgenen rol $A B C$ Kiwipflanzen und dessen Erbschaft in den T1-Nachkömmlingen Der staubgefäßtragende Kiwi (Actinidia delicosa A. Chev) cv. GTH (Late Yellow Hayward) zeigte eine hohe Resistenz gegenüber den Pathogenen Pseudomonas syringae $\mathrm{pv}$. syringae und $P$. viridiflava, im Gegensatz zu der stempeltragenden cv. Hayward, welche eine hohe Anfälligkeit gegenüber beiden Bakterien aufwies.
Die resistente staubgefäßtragende GTH erwarb eine Anfälligkeit nach einer Transformation mit rolABC von Agrobacterium rhizogenes. Diese Anfälligkeit wurde in den T1_Nachkömmlingen mit rolABC-Genen geerbt, die Nachkömmlinge wurden durch die Kreuzung von Blütenstaub des transgenen rol $A B C \mathrm{GTH}$ mit der stempeltragenden cv. Hayward erzeugt. Die Anfälligkeit der rolABC-Pflanzen war wahrscheinlich mit dem hohen Stickstoffgehalt der Blätter korreliert. Die höhere Anfälligkeit gegenüber $P$. s. pv. syringae als gegen $P$, viridiflava konnte mit der hohen Auxinproduktion bei $P$. s. pv. syringae korreliert werden. Die hohe Resistenz der staubgefäßtragenden GTH gegenüber beiden Bakterien wurde in allen Nachkömmlingen geerbt, die die rolABC-Gene nicht enthielten. Diskutiert wird über eine mögliche Reduktion der Anfälligkeit der rolABC-Pflanzen durch das Ausbringen von weniger Dünger in den Kiwiplantagen; eine Maßnahme, die sowohl Produktionskosten als auch den Einfluss auf den Umwelt reduzieren würde.

\section{Introduction}

Cultivation of kiwifruit (Actinidia deliciosa A. Chev) has spread recently to all temperate areas of the world, following the development of the culture during the 1960 s. For some years no particular phytopathological problems occurred in this cultivation but later some bacterial (Wilkie et al., 1973; Young et al., 1988; Serizawa et al., 1989) and fungal (Sale, 1981; Bisiach et al., 1984) diseases were recorded.

Significant damage can be caused by some of these pathogens such as Pseudomonas viridiflava 